IJ§ER

ISSN: 2149-5939
International Journal of Social Sciences and Education Research

Online, http://dergipark.gov.tr/ijsser

Volume: 3(5), 2017

\title{
Factors directing women workers working in the textile sector in Turkey to trade union membership: Example of Çorlu ${ }^{1}$
}

\author{
M. Engin Sanal ${ }^{2} \quad$ Nihan Çam $^{3} \quad$ Yasemin Koldere Akın $^{4}$ \\ Received Date: 10 / 02 / $2017 \quad$ Accepted Date: 08 / 06 / 2017
}

\begin{abstract}
The unionization of women in the world for various reasons differs from that of men. In Tekirda $\breve{g}$ province where the study has been conducted, it is observed that the unionization rates differ by gender around Turkey. As a result of the study, it was observed that especially the fact that women workers think that the trade union, which they are the member of, will help them in the problems they face at the workplace causes them to become the members of the trade union. Then, it was also observed that while thinking that there will be an increase in their incomes, the effect of trade union members in the individual's environment, social activities of the trade unions for the members and their families mostly affect the tendency to trade union membership, benefiting from social rights to be provided by the trade union membership takes the last place.
\end{abstract}

Keywords: Female workforce, Unionization, Textile industry, Çorlu

\section{Introduction}

The unionization of women around the world is different from that of men for various reasons. Many female workers are still unorganized despite the increase in the women employment especially in the service sector after 1980. Reasons such as the fact that women mainly work in the service sector under atypical employment patterns, unregistered employment, failure to take part in the union management to a sufficient extent, thinking that unions cannot adequately represent them result in a lower unionization rate among female workforce when compared to men. The fact that the trade union movement has been fed on a traditional member structure for long years, with male workers based on physical power, regularly working eight hours a day with a standard wage and low skill level in a secure working environment also has supported this situation (Selamoğlu, 2004). However, this in no way means that women show little interest in trade unions. Indeed, the rates of women's unionization rapidly increase in countries around the world where unionization is strong and even surpass men in countries such as the UK (Sanal, 2015). Similarly, in a study carried out in Turkey among university students, it has been found out that women are interested in trade union membership at least as much as men and even more (Seçer, 2009). These data show that women are actually potential members of trade unions.

All these factors affect the unionization of women in Turkey negatively. However, some of these factors come to the forefront in Turkey. The first of them is that women cannot be adequately represented in the management of trade unions. Despite the trade union managers' statements

\footnotetext{
${ }^{1}$ This study's method and results are part of Nihan Çam's thesis of master. This study was supported that by Trakya Universty Research Fundation (Project number 2011/20).

${ }^{2}$ Assoc. Prof. Dr., Trakya University, Edirne, TURKEY

${ }^{3}$ Trakya University, Edirne, TURKEY

${ }^{4}$ Asst. Prof. Dr., Trakya University, Edirne, TURKEY
} 
Sanal, M.E., Çam, N., Koldere Akın, Y. (2017). Factors directing women workers working in the textile sector in Turkey to trade union membership: Example of Çorlu. International Journal of Social Sciences and Education Research, 3(5), 1463-1470.

such as "we cannot find women who can become candidates", a study conducted in the banking, textile and trade-office business lines shows that $24 \%$ of women who have not taken part in the management of trade unions are willing to undertake such a duty. In a similar manner, this rate rises to one-third in a study conducted by a labour confederation (Türk-İş) (Toksöz, 1994). It is also observed that women trade union members cannot take part in the management of trade unions adequately despite their demands. For examples, as of 2015 , in total $3.57 \%$ of the union presidents, $3.93 \%$ of the members of the board of directors, $4.32 \%$ of the members of the board of supervisors, and $2.92 \%$ of the members of the discipline committee consists of women in Turkey (ÇSGB, 2016). This unjust distribution results in the inadequate representation of women in the management and activities of trade unions, and their remaining indifferent to the membership in trade unions.

Another factor is the low participation rates of women in the workforce in Turkey. In Turkey, while the rate of participation of men in the workforce in Turkey is $72 \%$ as of 2016 , it is $32.5 \%$ among women (TÜIK, 2017). In a study that covers $18 \mathrm{EU}$ member countries, the rates of the unionization of men are higher in ten of these countries. The main reason for this is that men, whose rates of participation in the workforce are higher, believe that being a member of a trade union will provide more favours (Sanal, 2015). The rate of the unionization of male workers is $11.77 \%$, while the rate of the unionization of female workers is $5.83 \%$ in Turkey, where the participation rates of women in the workforce are lower when compared to men (ÇSGB, 2016). In addition to the low rates of participation in the workforce, the glass walls that are formed as a result of social gender discrimination also affect the unionization rates of women negatively. For example, it is possible to observe this in the metal and petroleum - chemistry industries where the rates of unionization are high. According to a study that tries to measure the attitudes of the workers in these sectors in Eskişehir towards unionization, only 1.8\% of the trade union members consist of women. The reason for this is the low number of female workers who can become the members of trade unions in this sector, and most of female workers work in informal sectors (Uçkan and Kağnıcıoğlu, 2009). Similarly, in a study carried out in the business lines of weaving, food, petroleum-chemistry/tire and metal for the manufacturing industry in Kocaeli province, $85.9 \%$ of the participants consist of men, and $11.6 \%$ consist of women. The rate of the unionization of the participants is $70.4 \%$ among men, and $48.4 \%$ among women (Urhan and Selamoğlu, 2008). The fact that the weaving and food business lines have been included within the scope of the study has led to an increase in the number of female participants. However, the rate of unionization is still very low among women when compared to men.

Although the unionization rates of women are lower when compared to men, the studies and observations performed show that whatever the factor that motivates workers to membership is, trade unions are still the most important representatives of workers, and regardless of being unionized or not, a significant mass of workers perceive trade unions as a significant tool in protecting their economic and social interests (Urhan, 2012).

Apart from this general situation, when we examine the subject in terms of the limitations of the study, the textile industry has been included in the country's economy at high employment and production levels from the early Ottoman period up to the present time. Turkey is among the world's most important producers of cotton, which is the raw material of the textile sector, and has an advantageous position in terms of its closeness to active markets (Ercan, 2002). TekirdağÇorlu takes place near the top among the industrial centres in Turkey's manufacturing of textile 
Sanal, M.E., Çam, N., Koldere Akın, Y. (2017). Factors directing women workers working in the textile sector in Turkey to trade union membership: Example of Çorlu. International Journal of Social Sciences and Education Research, 3(5), 1463-1470.

products considering the number of establishments and insured employees. There are 681 enterprises manufacturing Textile, Clothes, and Leather in Tekirdağ province, and there are 64420 insured employees employed in these enterprises (SGK, 2015). 16.4\% of the industrial enterprises in Trakya Region are in Kırklareli, 15.6\% are in Edirne, and 68\% are in Tekirdağ (Kubaş, 2012). Considering the distribution of the industrial enterprises producing textile in Tekirdağ province by districts, it is observed that the majority is located in Çorlu region.

Another feature of Tekirdağ province where the study has been carried out is that the unionization rates by gender are different from Turkey in general, and while the unionization rates among male workers are $19.08 \%$, the unionization rates among female workers are $15.53 \%$ (ÇSGB, 2016). This makes Tekirdağ province, which constitutes the limitation of the study, significant. The main subject of this study is to contribute to determining the reasons why the female workers working in the textile sector in Çorlu district of Tekirdağ province become the members of trade unions. This contribution can also be taken into consideration in creating the policies that will contribute to female workers' that can potentially become trade union members becoming active trade union members because the factors that lead women to the trade union membership as a result of the study also show that trade unions are superior in organizing female workers. The increase in the unionization rates of women is also important in terms of supporting unionization in Turkey $(\mathrm{OECD}, 2017)$ with the lowest unionization rate among the OECD countries with $6.3 \%$ within the OECD average of $17 \%$.

\section{Method}

\subsection{Aim of the study}

The aim of the study is to determine the factors that lead the female workforce in the textile sector to becoming trade union members in Çorlu incorporating the highest number of industrial facilities in Tekirdağ province, which is among the leading manufacturing centres of Turkey for the textile sector by means of interpreting the data collected with the survey application.

\subsection{Population and sample of the study}

The population of the study that has been carried out in order to determine the attitudes of the female workforce in the textile sector in Turkey towards unionization consists of unionized women working in the textile sector in Çorlu district of Tekirdağ province. Information on the member numbers of Teksif labour union affiliated to Türk-İs and Öz iplik labour union affiliated to Hak-İs in the region was obtained as a result of individual interviews. The textile union affiliated to Disk was not included in the study since it does not have the sufficient number of members that can constitute a sample for research in Çorlu district.

Sampling is a method frequently used by researchers in various fields of science in order to be able to make a healthy estimation or make inferences in relation to population parameters. The healthy estimation of population parameters based on sample statistics is quite significant in terms of the mechanisms that must decide especially against uncertainties in the economy, business management and many other fields (Özsoy, 2005). The reliability of a sample is related to the closeness of the sample averages to the population average (Kaptan, 1983). The sample of our survey study, with an error margin of 5\% and at the confidence level of $95 \%$, was determined to be 323 female workers in total, 170 of them being from Teksif Union and 153 from Öz-İplik Labour Union. 
Sanal, M.E., Çam, N., Koldere Akın, Y. (2017). Factors directing women workers working in the textile sector in Turkey to trade union membership: Example of Çorlu. International Journal of Social Sciences and Education Research, 3(5), 1463-1470.

\subsection{Data Collection}

The face-to-face survey technique was used among primary data collection methods in the collection of the data in the study. The survey form includes 18 questions in total, 12 of which are of a demographic characteristic.

Three of the most important names of attitude scales in the past are Thurstone, Guttman, and Likert. Thurstone designed a method calculating the scale value of each attitude question by assuming that the questions on different attitudes correspond to different points on a single-dimension attitude line. Guttman suggested a scale that is suitable for the use of the questions together with the binary response format (yes-no) in the ranking of the questions by the attitude content in order to define people's place on the attitude line. Instead of giving a binary response to questions, Likert developed a method called the "total assessment method" or more commonly the "Likert scale". Likert's "total assessment method" is quite widely used in today's social studies, and it is the most common type of scale in measurement tools (Punch, 2005). The question suggestions in the questionnaire form were prepared in the form of five-point Likert-type scale questions. The survey participants were asked to express their opinions on ideas and attitudes by marking one of the following options: "Totally disagree, Disagree, I have no idea, Agree, Totally agree".

\subsection{Interpretation of the data}

SPSS 16.0 statistics packaged software was used in the interpretation of the data, and tables created with the calculated statistics such as percentage, frequency, arithmetic mean and standard deviation were used.

\subsection{Reliability measurement}

Reliability basically and simply means consistency in the measurement. There are random errors in unreliable scores. Firstly, it is required to determine the reliability of a scale since an unreliable scale cannot be valid as well (Tavşancıl, 2006).

It is assumed that the score distribution obtained from an item in a Likert-type attitude scale is a constant variable. One of the basic assumptions of this scale is that each item in the scale has a monotonic relationship with the measured attitude. Thus, it is suitable to use the $(\alpha)$ coefficient developed by Cronbach, which is a criterion of internal consistency, in order to determine the level of reliability in a Likert-type attitude scale. The Cronbach's $\alpha$ coefficient is a measurement of internal consistency of the items in the scale. A higher $\alpha$ coefficient of the scale shows that the items in the scale consist of the items that are consistent with each other in that scale and measure the elements with the same property. The level of reliability in the Likert-type attitude scale can also be estimated by means of the test-retest, but this level of reliability cannot be considered as a measurement of reliability alone since internally consistent items are sought in a Likert-type scale (Tavşancil, 2006).

The assessment criterion complied with in the assessment of the Alpha coefficient is as follows;

If $0.00 \leq \alpha<0.40$, then the scale is not reliable.

If $0.40 \leq \alpha<0.60$, then the scale is of low reliability.

If $0.60 \leq \alpha<0.80$, then the scale is quite reliable.

If $0.80 \leq \alpha<1.00$, then the scale is highly reliable (Tavşanc1l, 2006). 
Sanal, M.E., Çam, N., Koldere Akın, Y. (2017). Factors directing women workers working in the textile sector in Turkey to trade union membership: Example of Çorlu. International Journal of Social Sciences and Education Research, 3(5), 1463-1470.

\section{Findings of the study}

The distribution of the demographic characteristics of 323 female unionized workers that participated in the study in order to reveal the perceptions of the female workforce in the textile sector of unionization with regard to age, educational status, total years worked, duration of the membership to the trade union and trade union members in the family is presented in Table 1.

Table 1. Findings on the demographic characteristics of the participants

\begin{tabular}{|c|c|c|c|c|c|}
\hline Age & $\begin{array}{l}\text { Num- } \\
\text { ber }\end{array}$ & $\%$ & Marital Status & $\begin{array}{l}\text { Num- } \\
\text { ber }\end{array}$ & $\%$ \\
\hline $15-24$ & 19 & 5.9 & Married & 257 & 79.6 \\
\hline $25-34$ & 182 & 56.3 & Single & 31 & 9.6 \\
\hline $35-44$ & 48 & 14.9 & Divorced & 33 & 10.2 \\
\hline $45-54$ & 54 & 16.7 & Out of Assessment & 2 & 0.6 \\
\hline 55 and above & 20 & 6.2 & & & \\
\hline Number of Children & $\begin{array}{l}\text { Num- } \\
\text { ber }\end{array}$ & $\%$ & Educational Status & $\begin{array}{l}\text { Num- } \\
\text { ber }\end{array}$ & $\%$ \\
\hline None & 68 & 21.1 & Primary School & 106 & 32.8 \\
\hline 1 & 108 & 33.4 & Secondary School & 113 & 35 \\
\hline 2 & 107 & 33.1 & High School & 61 & 18.9 \\
\hline 3 & 39 & 12.1 & Undergraduate & 43 & 13.3 \\
\hline 4 and above & 1 & 0.3 & & & \\
\hline Total Years Worked & $\begin{array}{l}\text { Num- } \\
\text { ber }\end{array}$ & $\%$ & $\begin{array}{l}\text { Employment Status of the } \\
\text { Spouse }\end{array}$ & $\begin{array}{l}\text { Num- } \\
\text { ber }\end{array}$ & $\%$ \\
\hline Less than 2 years & 93 & 28.8 & Employed & 181 & 70.4 \\
\hline $2-6$ years & 107 & 33.1 & Unemployed & 76 & 29.5 \\
\hline $7-11$ years & 55 & 17 & & & \\
\hline $12-16$ years & 56 & 17.3 & & & \\
\hline 16 years and above & 12 & 3.7 & & & \\
\hline Monthly Income Status & $\begin{array}{l}\text { Num- } \\
\text { ber }\end{array}$ & $\%$ & $\begin{array}{l}\text { Duration of the Member- } \\
\text { ship to the Trade Union }\end{array}$ & $\begin{array}{l}\text { Num- } \\
\text { ber }\end{array}$ & $\%$ \\
\hline Less than 700 & 86 & 26.6 & Less than 2 years & 90 & 27.9 \\
\hline $701-1200$ & 142 & 44 & $2-6$ years & 139 & 43 \\
\hline $1201-1700$ & 81 & 25.1 & 7-11 years & 38 & 11.8 \\
\hline $1701-2200$ & 10 & 3.1 & $12-16$ years & 49 & 15.2 \\
\hline Out of Assessment & 4 & 0.6 & 16 years and above & 7 & 2.2 \\
\hline Unionized Family Members & $\begin{array}{l}\text { Num- } \\
\text { ber }\end{array}$ & $\%$ & & & \\
\hline $\begin{array}{l}\text { No trade union members in the } \\
\text { family }\end{array}$ & 143 & 44.3 & & & \\
\hline Spouse is a trade union member & 95 & 29.4 & & & \\
\hline Sibling is a trade union member & 34 & 10.5 & & & \\
\hline $\begin{array}{l}\text { Mother or father is a trade union } \\
\text { member }\end{array}$ & 25 & 7.7 & & & \\
\hline Child is a trade union member & 23 & 7.1 & & & \\
\hline Out of Assessment & 3 & 0.9 & & & \\
\hline
\end{tabular}


Sanal, M.E., Çam, N., Koldere Akın, Y. (2017). Factors directing women workers working in the textile sector in Turkey to trade union membership: Example of Çorlu. International Journal of Social Sciences and Education Research, 3(5), 1463-1470.

19 of 323 people that participated in the survey are between 15 and 24 years, 182 are between 25 and 34 years, 48 are between 35 and 44 years, and 54 are between 45 and 54 years. 20 participants are 55 years old and above. Upon examining the percentage distribution of age groups, it is observed that the majority is between 25 and 34 years old with a rate of $56.3 \%$.

$79.6 \%$ of the survey participants are married. The rate of singles is $9.6 \%$, while the rate of divorced participants is $10.2 \%$. 2 people left the question about their marital status blank. $33.4 \%$ of the participants have 1 child, $33.1 \%$ have 2 children, $12.1 \%$ have 3 children, and $0.3 \%$ have 4 and more children. $21.1 \%$ of the participants do not have children.

The data on the educational status of the participants show that most of the participants are secondary school graduates with a rate of $35 \% .32 .8 \%$ of the participants are primary school graduates. $67.8 \%$ of the participants consist of primary and secondary school graduates, while only $18.9 \%$ are high school graduates, and $13.3 \%$ have an undergraduate degree.

It is observed that $33.1 \%$ of the participants have 2-6 years of the work experience. Those who have the work experience of less than 2 years make up $28.8 \%$ of the participants, those with $7-11$ years of the work experience make up $17 \%$ of the participants, and those with 12-16 years of the work experience make up $17.3 \%$ of the participants. $3.7 \%$ of the participants have the work experience of 16 years and more.

While the spouses of 181 among 257 married survey participants are employed, the spouses of 76 participants are unemployed. Upon examining the percentage rates, it is observed that the spouses of $70.4 \%$ of married participants are employed, while the spouses of $29.5 \%$ are unemployed. The monthly family income of the most participants is between 701 and 1200 TL with a rate of $44 \%$. While the monthly income of $26.6 \%$ of the participants is below $700 \mathrm{TL}$, the monthly family income of $25.1 \%$ is between 1201 and 1700 TL. The monthly family income of only $3.1 \%$ of the participants is between 1701 and 2200 TL. Four participants are out of the assessment since they have left the question on their monthly family income blank.

All 323 trade union member female workers that participated in the survey answered the question on their job definition as "worker".

The answers of the participants to the questions aimed at revealing their reasons for becoming trade union members are summarized in Table 2.

Q1: The social rights it will provide have become effective in becoming a member of the trade union.

Q2: I became a trade union member since I believed that there would be an increase in my income.

Q3: The trade union members at my workplace and around me have become effective in my becoming a trade union member.

Q4: I became a member since I liked the social activities of trade unions for the members and their families.

Q5: I became a trade union member because I thought that it would help me in the problems I encountered at my workplace. 
Sanal, M.E., Çam, N., Koldere Akın, Y. (2017). Factors directing women workers working in the textile sector in Turkey to trade union membership: Example of Çorlu. International Journal of Social Sciences and Education Research, 3(5), 1463-1470.

Table 2. Findings on the reasons why the participants have become trade union members

\begin{tabular}{|c|c|c|c|c|c|c|c|c|}
\hline & $\begin{array}{l}\text { Totally Disa- } \\
\text { gree }\end{array}$ & Disagree & $\begin{array}{l}\text { I Have } \\
\text { No } \\
\text { Idea }\end{array}$ & Agree & Totally Agree & Total & Average & $\begin{array}{l}\text { Stand- } \\
\text { ard De- } \\
\text { viation }\end{array}$ \\
\hline \multirow[t]{2}{*}{ Q1 } & 70 & 56 & 43 & 91 & 63 & 323 & \multirow[t]{2}{*}{3.06} & \multirow[t]{2}{*}{1.450} \\
\hline & $21.7 \%$ & $17.3 \%$ & $13.3 \%$ & $28.2 \%$ & $19.5 \%$ & $100.00 \%$ & & \\
\hline \multirow[t]{2}{*}{ Q2 } & 34 & 70 & 32 & 107 & 80 & 323 & \multirow[t]{2}{*}{3.39} & \multirow[t]{2}{*}{1.343} \\
\hline & 10.5 & $21.7 \%$ & $9.9 \%$ & $33.1 \%$ & $24.8 \%$ & $100.00 \%$ & & \\
\hline \multirow[t]{2}{*}{ Q3 } & 45 & 63 & 46 & 96 & 73 & 323 & \multirow[t]{2}{*}{3.27} & \multirow[t]{2}{*}{1.372} \\
\hline & $13.9 \%$ & $19.5 \%$ & $14.2 \%$ & $29.7 \%$ & $22.6 \%$ & $100.00 \%$ & & \\
\hline \multirow[t]{2}{*}{ Q4 } & 50 & 93 & 41 & 36 & 103 & 323 & \multirow[t]{2}{*}{3.15} & \multirow[t]{2}{*}{1.509} \\
\hline & $15.5 \%$ & $28.8 \%$ & $12.7 \%$ & $11.1 \%$ & $31.9 \%$ & $100.00 \%$ & & \\
\hline \multirow[t]{2}{*}{ Q5 } & 45 & 59 & 30 & 89 & 100 & 323 & \multirow[t]{2}{*}{3.43} & \multirow[t]{2}{*}{1.439} \\
\hline & $13.9 \%$ & $18.3 \%$ & $9.3 \%$ & $27.6 \%$ & $31.0 \%$ & $100.00 \%$ & & \\
\hline
\end{tabular}

$31.9 \%$ of those who participated in the survey stated that the social activities provided by trade unions for the members and their families became effective in their becoming a trade union member. 187 of the participants marked the option "agree" in the question that they became trade union members by thinking that there would be an increase in their income. 189 people stated that thinking that the trade union would help them in the problems they encountered at the workplace became effective in their becoming trade union members, while 169 people stated that the trade union members at their workplace and around them became effective in their becoming trade union members. While 91 people agreed that the social rights to be provided were effective in becoming a trade union member, 63 people answered the same question by marking the option of totally agree. However, while 70 of the participants answered the same question as totally disagree, 56 of them marked the option disagree. 143 people answered the fourth question on the effect of the social activities for trade union members and their families in becoming a trade union member as "disagree" and "totally disagree".

\section{Conclusion}

In Turkey's manufacturing of textile products, Tekirdağ - Çorlu is among the industry centres at the highest places considering the number of workplaces and insured workers. As a result of the study carried out on unionized women working in the textile sector in Çorlu district of Tekirdağ province for the purpose of determining the factors that lead the female workforce in the textile sector in Turkey to becoming trade union members, it was observed that the primary reason why female workers become trade union members is their thinking that their trade union will help them in the problems they encounter at the workplace. This is mainly followed by the belief that there will be an increase in their income. These two reasons are generally among the main factors that lead individuals to becoming trade union members. This is extremely natural because trade unions are organizations that undertake the duty of protecting and developing the economic and social rights and interests of their members in addition to their representative properties.

The effect of the trade union members around the individual comes at the third place. The positive contribution of the social environment to the trade union membership does not differ 
Sanal, M.E., Cam, N., Koldere Akın, Y. (2017). Factors directing women workers working in the textile sector in Turkey to trade union membership: Example of Çorlu. International Journal of Social Sciences and Education Research, 3(5), 1463-1470.

much from the first two factors and ranks among the three main factors that lead female workers to becoming trade union members. Whether there is a trade union member in the family environment in which the individual socializes and his/her opinion about trade unions are especially effective in this respect. Whether their spouses and friends are trade union members and their opinions about trade unions are also important. The fact that the family is a role model in the socialization process, the presence of a trade union member in the family and/or a positive perception and discourse on trade unions are also important. The social environment of the individual is added to the family at later ages.

Fourthly, the presence of the social activities of trade unions for their members and their families is effective in the membership. While it is observed that especially such services as education, health and social services, the presence of educational, health and leisure facilities, cooperatives for members, charity funds, cheap shopping and credit facilities, etc. are effective in becoming trade union members, benefiting from the social rights to be provided by the trade union membership comes at the last place.

\section{References}

Çalışma ve Sosyal Güvenlik Bakanlı̆̆g. (2017, Feb 17). Çalışma Hayatı İstatistikleri 2016. https://www.csgb.gov.tr/media/3299/calisma_hayati_2015.pdf.

Ercan, E. (2002). Changing Word Trade Conditions Force The Turkish Textile and Apparel Industry to Create New Strategies, Izmir University of Economics, 2 (4).

Kaptan, S. (1983). Bilimsel Araştırma ve İstatistik Teknikleri. Ankara: Bilim Yayınları.

Kubaş, A. (2012). Trakya Bölgesinde Sınai Yapı ve Sanayileşme. Ankara: Türkiye Ekonomi Kurumu.

OECD. (2017, Feb 17). Trade Union Density, OECD Statistics, http://stats.oecd.org/.

Özsoy, O. (2005). İktisatçılar ve İşletmeciler için İstatistik. Ankara: Siyasal Kitabevi.

Punch, K. F. (2005). Sosyal Araştırmalara Giriş: Nicel ve Nitel Yaklaşımlar. Ankara: Siyasal Kitabevi.

Sanal, M. E. (2015). Gelişmiş Ekonomilerde Dönüşen Kapitalizmin Endüstri ilişkilerine Etkileri. Paradigma Akademi Yayınları.

Seçer, B. (2009). Kadınların Sendikalara Yönelik Tutumları İle Cinsiyet Ayrımcılı̆̆ı Algılarının Sendika Üyesi Olma İsteğine Etkisi. Çalışma ve Toplum, 2009/4, $27-60$.

Selamoğlu, A. (2004). Örgütlenme Sorunu Ve Sendikal Yapıda Değişim Arayışı. Çalışma ve Toplum, 2004/2, 39-54.

Sosyal Güvenlik Kurumu. (2017, Feb 22). 2015 İstatistik Y1llkları. http://www.sgk.gov.tr/wps/portal/sgk/tr/kurumsal/istatistik/sgk_istatistik_yilliklari.

Tavşancıl, E. (2006). Tutumların Ölçülmesi ve SPSS ile Veri Analizi. Ankara. Nobel Yayın Dağıtım.

Toksöz, G. (1994). Kadın Çalışanlar ve Sendikal Katılım. Ankara Üni. SBF Dergisi, 49 (3), 439 -454.

Türkiye İstatistik Kurumu. (2017, March 23). İşgücü İstatistikleri 2016. http://www.tuik.gov.tr/PreHaberBultenleri.do?id=24635.

Uçkan, B. and Kağnıcıoğlu, D. (2009). İşçilerin Sendikalara İlişkin Algı ve Tutumları: Eskişehir Örneği. Çalışma ve Toplum, 2009/3, 35 - 56.

Urhan, B. and Selamoğlu, A. (2008). İşçilerin Sendikalara Yönelik Tutum ve Davranışları; Kocaeli Örneği. Çalışma ve Toplum, 2008/3, 171 - 197.

Urhan, B. (2012). İşçilerin Sendikaya Üye Olma Nedenleri ve Sendikaların Yeni Üye Kazanmaya Yönelik Stratejileri. Is, Guc" Industrial Relations And Human Resources Journal, 14 (2), 33-56. 